\title{
PENGARUH PERSENTASE PENAMBAHAN SIKA VISCOCRETE-10 TERHADAP KUAT TEKAN BETON
}

\author{
Muhammad Zardi ${ }^{1}$, Cut Rahmawati ${ }^{2}$, T.Khamarud Azman ${ }^{3}$ \\ 1),2),3) Program Studi Teknik Sipil, Fakultas Teknik, Universitas Abulyatama \\ Jl. Blang Bintang Lama Km 8,5 Lampoh Keude Aceh Besar, \\ email:mr_zardi@yahoo.com,profestama7@yahoo.co.id
}

\begin{abstract}
Building structure often use concrete as the main structural material, in which the concrete-forming materials such as cement, sand, gravel, water and additives. The aim of study is to investigate the influence of addition of Sika Viscocrete-10 toward concrete compressive strength. Concrete is planned with Water Cement Ratio 0.3. Slump values obtained for normal concrete with maximum aggregate diameter of $25.4 \mathrm{~mm}$ is $7.8 \mathrm{~cm}$. The values are in accordance with the slump plan of 7.5 to $10 \mathrm{~cm}$, meanwhile values slump that use Sika Viscocrete-10 as much as $0.5 \%$ is $19.5 \mathrm{~cm}$; Sika Viscocrete-10 as much as $1 \%$ is $21.9 \mathrm{~cm}$; Sika Viscocrete-10 as much as 1.5\% is $23 \mathrm{~cm}$; and Sika Viscocrete-10 as much as $1.8 \%$ is 24.7 $\mathrm{cm}$. Based on these test results, the conclusion is addition of Sika Viscocrete-10 is able to enhance the workability value of concrete, so it is easy to work. Concrete mix design using the American Concrete Institute (ACI). Specimens used in this study is a standard concrete cylinder diameter of $150 \mathrm{~mm}$ and a height of $300 \mathrm{~m}$, tested after the age of 14 days. Number of test specimens for all treatments is 25 with 5 specimens in each treatment. The average compressive strength of concrete with normal mixture is $295.43 \mathrm{~kg} / \mathrm{cm}^{2}$; for concrete with Sika Viscocrete-10 as mush as $0.5 \%$ is of $376.50 \mathrm{~kg} / \mathrm{cm}^{2}$; Sika Viscocrete-10 as mush as $1 \%$ is $452.94 \mathrm{~kg} / \mathrm{cm}^{2}$; Sika Viscocrete-10 as mush as $1.5 \%$ is $501.63 \mathrm{~kg} / \mathrm{cm}^{2}{ }^{2}$ and Sika Viscocrete-10 as mush as $1.8 \%$ is $515.78 \mathrm{~kg} / \mathrm{cm}^{2}$. Concrete compressive strength greater with increasing percentage of Sika Viscocrete-10.
\end{abstract}

Keywords : compressive strength, slump, water cement ratio, workability, sika viscocrete-10.

\begin{abstract}
Abstrak: Struktur bangunan umumnya menggunakan beton sebagai bahan struktur utama, dimana bahan-bahan pembentuk beton berupa semen, pasir, kerikil, air dan juga bahan tambahan. Penelitian ini bertujuan untuk mengetahui pengaruh persentase penambahan Sika Viscocrete-10 terhadap kuat tekan beton. Beton direncanakan dengan FAS 0,3. Nilai slump yang diperoleh untuk beton normal diameter agregat maksimum $25,4 \mathrm{~mm}$ adalah $7,8 \mathrm{~cm}$. Nilai tersebut telah sesuai dengan nilai slump rencana yaitu $7,5-10 \mathrm{~cm}$, sedangkan nilai slump yang menggunakan Sika Viscocrete-10 sebanyak 0,5\% adalah 19,5 cm; Sika Viscocrete-10 sebanyak $1 \%$ adalah $21,9 \mathrm{~cm}$; Sika Viscocrete-10 sebanyak 1,5\% adalah $23 \mathrm{~cm}$; dan Sika Viscocrete-10 sebanyak $1,8 \%$ adalah $24,7 \mathrm{~cm}$. Berdasarkan hasil pengujian tersebut diperoleh kesimpulan bahwa penambahan sika viscocrete-10 mampu meningkatkan nilai workabilitas beton, sehingga mudah dikerjakan. Perencanaan campuran beton (mix design) menggunakan metode American Concrete Institute (ACI). Benda uji yang digunakan pada penelitian ini adalah beton silinder standar berdiameter $150 \mathrm{~mm}$ dan tinggi $300 \mathrm{~mm}$ yang diuji setelah berumur 14 hari. Jumlah benda uji untuk semua perlakuan adalah 25 dengan 5 benda uji pada masing-masing perlakuan. Kuat tekan rata-rata campuran beton normal sebesar $295,43 \mathrm{~kg} / \mathrm{cm}^{2}$; untuk beton dengan penambahan Sika Viscocrete-10 sebanyak 0,5\% sebesar $376,50 \mathrm{~kg} / \mathrm{cm}^{2}$; Sika Viscocrete-10 sebanyak $1 \%$ sebesar $452,94 \mathrm{~kg} / \mathrm{cm}^{2}$; Sika Viscocrete-10 sebanyak 1,5\% sebesar $501,63 \mathrm{~kg} / \mathrm{cm} 2$; dan Sika Viscocrete10 sebanyak 1,8\% sebesar $515,78 \mathrm{~kg} / \mathrm{cm}^{2}$. Kuat tekan beton semakin besar seiring dengan bertambahnya persentase Sika Viscocrete-10.
\end{abstract}

Kata kunci : kuat tekan, slump, FAS, workabilitas, sika viscocrete-10. 
Beton merupakan salah satu bahan pembentuk elemen konstruksi yang sangat banyak digunakan karena mudah dikerjakan, memiliki kuat tekan yang besar dan tahan terhadap perubahan cuaca. Di sisi lain, bahanbahan pembentuknya pun mudah didapatkan karena merupakan material alam yang melimpah seperti pasir, kerikil dan air. Meskipun pelaksanaan pekerjaan beton dikategorikan mudah, dalam kenyataannya masih sering dijumpai adanya elemen struktur konstruksi beton yang tidak terpenuhi nilai kuat tekannya. Hal ini umumnya disebabkan kesulitan pengecoran beton dan tidak dilakukan pemadatan secara baik, ataupun karena dilakukannya penambahan air campuran beton oleh pelaksana di lapangan sehingga menaikkan Faktor Air Semen (FAS) dari beton yang umumnya direncanakan dengan slump rendah. Oleh karena itu dibutuhkan campuran beton yang mudah dilaksanakan.

Untuk mendapatkan beton mutu tinggi maka harus digunakan FAS rendah, namun jika FAS-nya terlalu kecil pengerjaan beton akan menjadi sangat sulit, sehingga pemadatannya tidak bisa maksimal dan mengakibatkan beton menjadi keropos, hal tersebut berakibat menurunnya kuat tekan beton. Untuk Mengatasi hal tersebut dapat dipergunakan superplasticizer untuk meningkatkan workability (kemudahan pengerjaan) atau mengurangi kekentalan adukan dengan FAS yang sama dan menambah nilai kuat tekan beton yaitu Sika Viscocrete-10 yang merupakan generasi terbaru dari superplasticizer untuk beton dan mortar. Sika Viscocrete-10 ini secara khusus dikembangkan untuk produksi beton dengan kemudahan mengalir.

Penelitian ini bertujuan untuk mengetahui Pengaruh Persentase Penambahan Sika Viscocrete-10 Terhadap Kuat Tekan Beton seberat $0.5 \%, 1 \%, 1,5 \%$ dan $1,8 \%$ dari berat semen pada campuran beton berdiameter agregat maksimum 25,4 mm dengan FAS 0,3 .

\section{KAJIAN PUSTAKA}

Istimawan (1994) berpendapat, bahwa beton didapat dari pencampuran bahan-bahan agregat halus dan kasar yaitu pasir, batu, batu pecah atau bahan semacam lainnya. Agregat halus dan kasar disebut sebagai bahan susun kasar campuran, merupakan komponen utama beton. Nilai kekuatan serta daya tahan (durability) beton merupakan fungsi dari banyak faktor, diantaranya adalah nilai banding campuran dan mutu bahan susun, metode pelaksanaan pengecoran, pelaksanaan finishing, temperatur dan kondisi perawatan pengerasannya.

\section{Faktor Air Semen (FAS)}

Faktor air semen (FAS) adalah perbandingan antara berat air dan berat semen.

$$
\text { FAS }=\frac{\text { berat air }}{\text { berat semen }}
$$


Mulyono (2005) berpendapat menyatakan, air diperlukan pada pembuatan beton untuk memicu proses kimiawi semen, membasahi agregat, dan memberikan kemudahan dalam pekerjaan beton (workability). Untuk air yang terlalu sedikit menyebabkan proses hidrasi tidak tercapai seluruhnya sehingga akan mempengaruhi kekuatan beton, oleh karena itu perbandingan air dengan semen (faktor air semen) menjadi penting.

Murdock (1999) berpendapat bahwa untuk semua tujuan, beton yang mempunyai faktor air semen minimal dan cukup untuk memberikan workabilitas tertentu yang dibutuhkan untuk pemadatan yang sempurna tanpa pekerjaan pemadatan yang berlebihan, merupakan beton yang terbaik .

\section{Sifat-Sifat Fisis Agregat}

Agregat berfungsi sebagai bahan pengisi, tetapi peranannya dalam menentukan kekuatan beton lebih kecil daripada semen. Agregat dengan sifat kekerasan, kepadatan, dan keawetan tinggi mempunyai sifat kekekalan yang baik, sehingga akan menghasilkan beton yang berkualitas tinggi. Pemeriksaan sifat-sifat fisis agregat meliputi pemeriksaan berat jenis (specific gravity), penyerapan (absorbs), berat volume agregat (bulk density), analisa saringan (sieve analysis) agregat, modulus kehalusan (fineness modulus), gradasi agregat, kadar air agregat.
Berat jenis (specific gravity) dan penyerapan (absorption) agregat

Berat jenis agregat adalah perbandingan berat sejumlah volume agregat tanpa mengandung rongga udara terhadap berat agregat dengan volume yang sama. Anonim (1995) berpendapat bahwa berat jenis agregat terdiri dari dua keadaan yaitu keadaan jenuh permukaan (saturated surface dry) dan keadaan kering oven (oven dry). Lebih lanjut Amri (2005:10) berpendapat bahwa berat jenis agregat adalah $2300-2500 \mathrm{~kg} / \mathrm{m}^{3}$.

\section{Berat volume agregat (bulk density)}

Berat volume agregat (bulk density) adalah perbandingan berat agregat hasil pemadatan standar pada keadaan kering oven terhadap volume literan (container). Berat volume kering agregat sekitar $1200-1750$ $\mathrm{kg} / \mathrm{m}$. berat agregat halus dan kasar berkisar antara 1691 - 2245 ini identik dengan 77 $89 \%$ berat beton atau $67-82 \%$. Dapat dihitung sesuai dengan persamaan 2 .

$$
\mathrm{Wv}=\frac{W c a-W c}{V c}
$$

\section{Dimana :}

$\mathrm{Wv}=$ berat volume agregat $(\mathrm{kg} / \mathrm{liter})$;

$\mathrm{Wca}=$ berat container $(\mathrm{kg})$;

$\mathrm{Vc}=$ volume container (liter).

\section{Gradasi agregat}

Gradasi agregat adalah distribusi dari variasi ukuran butir agregat. Gradasi agregat berpengaruh pada besarnya rongga dalam campuran dan menentukan workabilitas (kemudahan dalam pekerjaan) serta stabilitas campuran. Gradasi agregat ditentukan dengan 
cara analisa saringan, dimana sampel agregat harus melalui satu set saringan. Ukuran saringan menyatakan ukuran bukaan jaringan kawat dan nomor saringan menyatakan banyaknya bukaan jaringan kawat per inchi pesegi dari saringan tersebut, daerah grafik gradasi agregat bisa dilihat pada gambar 1.

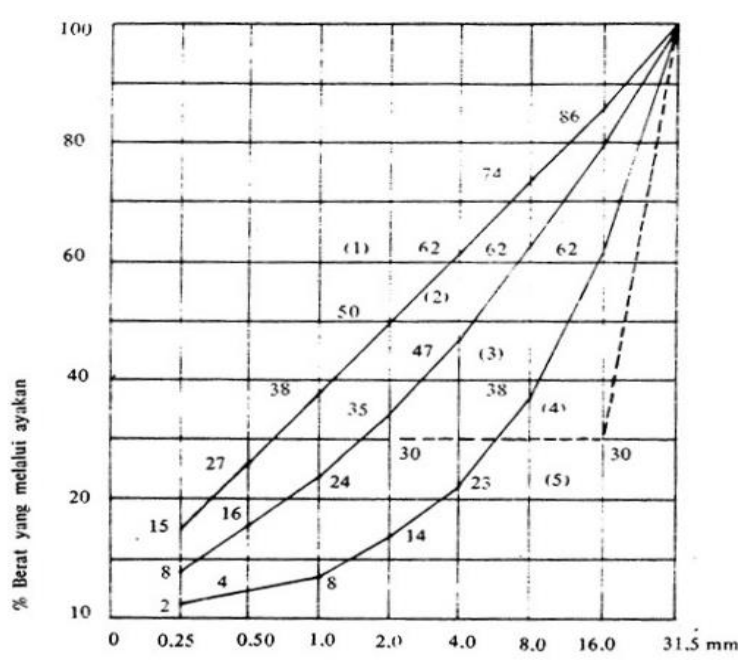

Gambar 1. Grafik daerah susunan butiran untuk agregat campuran dengan diameter maksimum 25,4 mm

Sumber: PBI 1971

Angka-angka dalam kurung pada Gambar 1 mempunyai arti:

(1). Daerah tidak baik, diperlukan banyak semen dan air;

(2). Daerah baik, tetapi diperlukan banyak semen dan air dibandingkan dengan daerah (3);

(3). Daerah baik sekali;

(4). Daerah tidak baik untuk susunan butiran diskontinu;

(5). Daerah sangat tidak baik, terlalu sulit dikerjakan

\section{Pengaruh Bahan Tambah}

Admixture adalah bahan-bahan yang ditambahkan kedalam campuran beton pada saat atau selama pecampuran berlangsung. Fungsi dari bahan ini adalah untuk mengubah sifat-sifat dari beton agar menjadi lebih cocok untuk pekerjaan tertentu

Penambahan Superplasticizer pada beton mempunyai pengaruh dalam meningkatkan kemudahan pekerjaan (Workability) beton sampai pada tingkat yang lebih besar. Bahan ini digolongakan sebagai sarana untuk menghasilkan beton mengalir tanpa terjadinya pemisahan yang diinginkan, dan umumnya terjadi pada beton dengan jumlah air yang besar, karena memungkinkan pengurangan kadar air guna mempertahankan kemudahan pekerjaan (Workability) yang sama, Mulyono (2004:124). Kelebihan Sika Viscocrete 10 sebagai Superplasticizer yang sangat kuat bekerja dengan berbagai mekanisme yang berbeda. Melalui penyerapan permukaan dan efek memisahkan butiran semen akan diperoleh sifat-sifat sebagai berikut:

a. Pengurangan air dalam jumlah besar, menghasilkan kepadatan tinggi, beton mutu tinggi dan mengurangi Permeabilitas.

b. Efek Plasticizing (pengurang air) yang sangat baik, menghasilkan kelecakan yang lebih baik, kemudahan pengecoran dan pemadatan sehingga sangat cocok digunakan untuk beton yang 
memadat dengan sendirinya (Self

Compacting Concrete);

c. Mengurangi penyusutan dan

keretakan.

d. Mengurangi karbonasi.

e. Meningkatkan sifat kedap air (Watertight).

\section{Kuat tekan Beton}

Dipohusodo (1994:7) berpendapat bahwa kuat tekan masing-masing benda uji ditentukan oleh tegangan tekan tertinggi $\left(f^{\prime} c\right)$ yang dicapai benda uji umur 28 hari akibat beban tekan selama percobaan.

Kuat tekan beton dapat dihitung dengan menggunakan persamaan 3 .

$$
f^{\prime} c=\frac{P}{A}
$$

Dimana :

$F^{\prime} c=$ kuat tekan silinder beton $\left(\mathrm{kg} / \mathrm{cm}^{2}\right)$;

$\mathrm{P} \quad=$ beban tekan maksimum/hancur $(\mathrm{kg})$;

A = luas penampang benda uji $\left(\mathrm{cm}^{2}\right)$.

\section{Rancangan Campuran Beton}

Metode rancangan campuran beton (concrete mix design) antara lain dihitung berdasarkan metode American Concrete Institute (ACI) 211.1-91 untuk beton normal sedangkan untuk penambahan Sika Viscrocrete-10 berdasarkan perbandingan berat semen. Metode rancangan beton dapat dihitung sesuai dengan persamaan 4 .

$$
\mathrm{FM}_{(\mathrm{FS})} \mathrm{X}+\mathrm{FM}_{(\mathrm{CS}) \cdot}(1-\mathrm{X})=\mathrm{FM}_{(\mathrm{FA})}
$$

Dimana :

$\mathrm{FM}_{(\mathrm{FS})}=$ Fineness Modulus dari pasir halus (fine sand)
$\mathrm{FM}_{(\mathrm{cs})}=$ Fineness Modulus dari pasir kasar (coarse sand)

$\mathrm{FM}_{(\mathrm{FA})}=$ Fineness Modulus dari agregat halus (fine agregat)

$\mathrm{X}=$ Bagian dari pasir halus

$1-\mathrm{X}=$ Bagian dari pasir kasar

\section{METODE PENELITIAN}

Penelitian ini dimulai dengan studi literatur, dilanjutkan dengan persiapan peralatan dan pengadaan material, pemeriksaan sifat-sifat fisis agregat, penggambaran gradasi agregat campuran. Selanjutnya perencanaan komposisi beton (concrete mix design), pengecoran beton, pengujian beton segar, pembuatan benda uji, perawatan benda uji, lalu dilanjutkan dengan pengujian beton (kuat tekan) 14 hari, serta pengolahan data.

\section{Bahan Material}

Material yang digunakan dalam penelitian ini adalah :

1. Semen Portland (PC)

2. Split 1-2

3. Split $2-3$, terdiri atas pasir halus (fine sand) dan pasir kasar (coarse sand)

4. Sika Viscocrete-10

5. Air.

Semen yang digunakan dalam penelitian ini adalah semen Portland tipe I yang diproduksi oleh PT. Semen Andalas Indonesia (SAI). Semen hanya diperiksa kehalusannya (tidak bergumpal) dan kantong pembungkusnya (tidak robek) secara visual. Pemeriksaan yang lainnya tidak dilaksanakan 
dengan pertimbangan semen yang digunakan telah memenuhi Standar Nasional Indonesia (SNI) No. 15-2049-1994 dan ASTM. C 59579. Sika Viscocrete 10 digunakan di produksi oleh PT. Sika Indonesia.

\section{Perencanaan campuran beton}

Pengecoran campuran beton (concrete mix design) direncanakan berdasarkan metode American Concrete Institute (ACI 211.1-91). Berdasarkan metode tersebut diperoleh berat masing-masing material yang digunakan, yaitu jumlah agregat, semen dan air. Untuk rancangan campuran beton direncanakan dengan FAS dasar 0,30 menggunakan agregat split. Ditambahkan zat aditif Sika Viscocrete-10 dengan perentase $0,5 \%, 1,0 \%, 1,5 \%$ dan $1,8 \%$ dari berat semen.

\section{Pemeriksaan Nilai Slump}

Alat uji slump terutama dipakai untuk mengukur campuran beton dalam keadaan plastis dan digunakan pada campuran beton yang sangat kering atau basah, serta untuk agregrat maksimum 25,4 mm dengan rencana nilai slump test 75-100 mm.

\section{Pembuatan benda uji}

Pembuatan benda uji beton dilakukan dengan memasukkan beton segar kedalam cetakan yang telah disediakan di laboratorium. Cetakan ini diisi bertahap dalam tiga lapisan, setelah cetak benda uji silinder dioles dengan minyak, kemudian dilakukan pemadatan dengan menusukkan tongkat baja sebanyak 25 kali pada setiap lapisannya. Setelah cetakan penuh, sisi cetakan benda uji diketuk-ketuk dengan palu karet agar lubang bekas tusukan menutup kembali, lalu setelah 4 jam dari waktu pengecoran, bagian atas benda uji di buat capping. Benda uji yang dibuat berjumlah 25 buah untuk pengujian kuat tekan.

Tabel 1. Jumlah Benda Uji dengan FAS 0,30 waktu pengujian 14 hari

\begin{tabular}{|c|c|c|c|c|c|}
\hline \multirow{2}{*}{$\begin{array}{c}\text { Jenis } \\
\text { Benda Uji }\end{array}$} & \multirow{2}{*}{$\begin{array}{c}\text { Beton } \\
\text { normal } \\
0 \%\end{array}$} & \multicolumn{4}{|c|}{$\begin{array}{c}\text { Kadar penambahan Sika } \\
\text { viscocrete-10 dari berat semen }\end{array}$} \\
\hline & & $0,5 \%$ & $1,0 \%$ & $1,5 \%$ & $1,8 \%$ \\
\hline $\begin{array}{l}\text { Silinder } \\
(Ø 15 \mathrm{~cm} \mathrm{x} \\
300 \mathrm{~cm})\end{array}$ & 5 & 5 & 5 & 5 & 5 \\
\hline
\end{tabular}

\section{HASIL DAN PEMBAHASAN}

\section{Sifat-Sifat Fisis Agregat}

Pemeriksaan sifat fisis mencakup Bulk density, Spesific Gravity (SSD), Spesific Gravity (OD), Absorbsi dan susunan gradasi butiran agregat. Hasil pemeriksaan menunjukkan bahwa agregat yang digunakan memenuhi syarat American Concrete Institute (ACI) sebagai material pembentuk beton.

\section{Pemeriksaan sifat fisis}

Pemeriksaan sifat material dilakukan terhadap seluruh material yang dipakai mencakup : agregat kasar dan agregat halus, agregat kasar berupa batu split sedangkan agregat halus mencakup pasir halus dan pasir kasar

Dalam penelitian ini diameter agregat maksimum yang digunakan adalah 25,4 mm. Rangkuman hasil pemeriksaan sifat fisis agregat diperlihatkan pada Tabel 2 . 
Tabel 2. Sifat Fisis Agregat

\begin{tabular}{|c|c|c|c|c|}
\hline Sifat fisis & $\begin{array}{c}\text { Corse } \\
\text { agregat } \\
\text { (ca) } \\
\text { Diameter } \\
\text { Maksimu } \\
\mathbf{m} \mathbf{2 5 , 4} \\
\mathbf{m m}\end{array}$ & $\begin{array}{c}\text { Coarse } \\
\text { Sand } \\
\text { (cs) }\end{array}$ & $\begin{array}{c}\text { Fine } \\
\text { Sand } \\
\text { (fs) }\end{array}$ & $\begin{array}{c}\text { Syarat } \\
\text { ACI }\end{array}$ \\
\hline $\begin{array}{c}\text { Bulk } \\
\text { density }\end{array}$ & 1,568 & 1,654 & 1,624 & $1.50-2.50$ \\
\hline $\begin{array}{c}\text { Spesific } \\
\text { Gravity } \\
\text { (SSD) }\end{array}$ & 2,795 & 2,508 & 2,554 & $2.00-3.20$ \\
\hline $\begin{array}{c}\text { Spesific } \\
\text { Gravity } \\
\text { (OD) }\end{array}$ & 2,755 & 2,437 & 2,450 & $2.00-3.20$ \\
\hline Absorbsi & 1,427 & 2,904 & 4.243 & - \\
\hline $\begin{array}{c}\text { Fineness } \\
\text { Modulus } \\
\text { (FM) }\end{array}$ & 2,002 & 3,724 & 2,863 & \\
\hline
\end{tabular}

Hasil pemeriksaan agregat menunjukkan agregat yang digunakan dalam penelitian ini sudah memenuhi persyaratan sebagai material beton. Nilai absorbsi material yang digunakan berkisar 1,427\% - 2,904 \% lebih kecil dari 5\% yang mengidentifikasikan bahwa materialnya dikategorikan baik.

\section{Susunan butiran Gradasi agregat}

Susunan butiran gradasi agregat diperiksa dengan menggunakan susunan ayakan dari no $25,4 \mathrm{~mm}$ sampai dengan no 0,15 $\mathrm{mm}$, dan hasil pemeriksaan tersebut ditampilkan dalam tabel analisa saringan. Dari hasil pemeriksaan tersebut diperoleh grafik gradasi dan fineness modulusnya. Nilai deviasi agregat yang lolos terhadap nilai median zona antara 2 - 3 disajikan dalam Tabel 3 .
Tabel 3. Hasil Perhitungan Klasifikasi Zona Agregat Campuran dengan Diameter Maksimum $25,4 \mathrm{~mm}$

\begin{tabular}{|c|c|c|c|c|}
\hline $\begin{array}{l}\text { Ukuran } \\
\text { Saringan }\end{array}$ & $\begin{array}{c}\text { Persen } \\
\text { Lolos }\end{array}$ & $\begin{array}{c}\text { Persen } \\
\text { ideal } \\
\text { zona } \\
\text { antara } \\
2-3 \\
\end{array}$ & $\begin{array}{l}\text { Nilai } \\
\text { Deviasi } \\
(\%)\end{array}$ & $\begin{array}{c}\text { Total } \\
\text { Nilai } \\
\text { Deviasi } \\
\text { Terhadap } \\
\text { Zona 2-3 }\end{array}$ \\
\hline 25,4 & 100 & 100 & \multirow{9}{*}{$1,11 \%$} & \multirow{9}{*}{ Zona 2} \\
\hline 19,10 & 94,867 & 65 & & \\
\hline 9,52 & 37,554 & 42 & & \\
\hline 4,76 & 28,872 & 35 & & \\
\hline 2,38 & 23,218 & 28 & & \\
\hline 1,18 & 16,895 & 21 & & \\
\hline 0,59 & 9,11 & 5 & & \\
\hline 0,30 & 3,074 & 0 & & \\
\hline 0,15 & 0 & 0 & & \\
\hline
\end{tabular}

Nilai deviasi agregat yang lolos terhadap nilai median zona antara 2 dan 3, untuk agregat campuran beton berdiameter agregat maksimum $25,4 \mathrm{~mm}$ adalah $1,11 \%$. Hal ini menunjukan bahwa diameter agregat maksimum 25,4 mm berada pada zona 2 dimana zona ini menunjukkan daerah yang baik, akan tetapi diperlukan jumlah semen dan air yang banyak sewaktu melakukan pengecoran. Untuk lebih jelas dapat dilihat pada Gambar 2.

\section{Rancangan Campuran Beton}

Campuran beton direncanakan dengan menggunakan semen, pasir halus, pasir kasar, kerikil dan bahan tambah (additive) sika viscocrete-10. Nilai slump rencana berkisar $7,5-10 \mathrm{~cm}$, dengan diameter agregat maksimum 25,4 mm. Hasil perencanaan campuran beton untuk 1 kali pengadukan molen disajikan pada Tabel 4. 


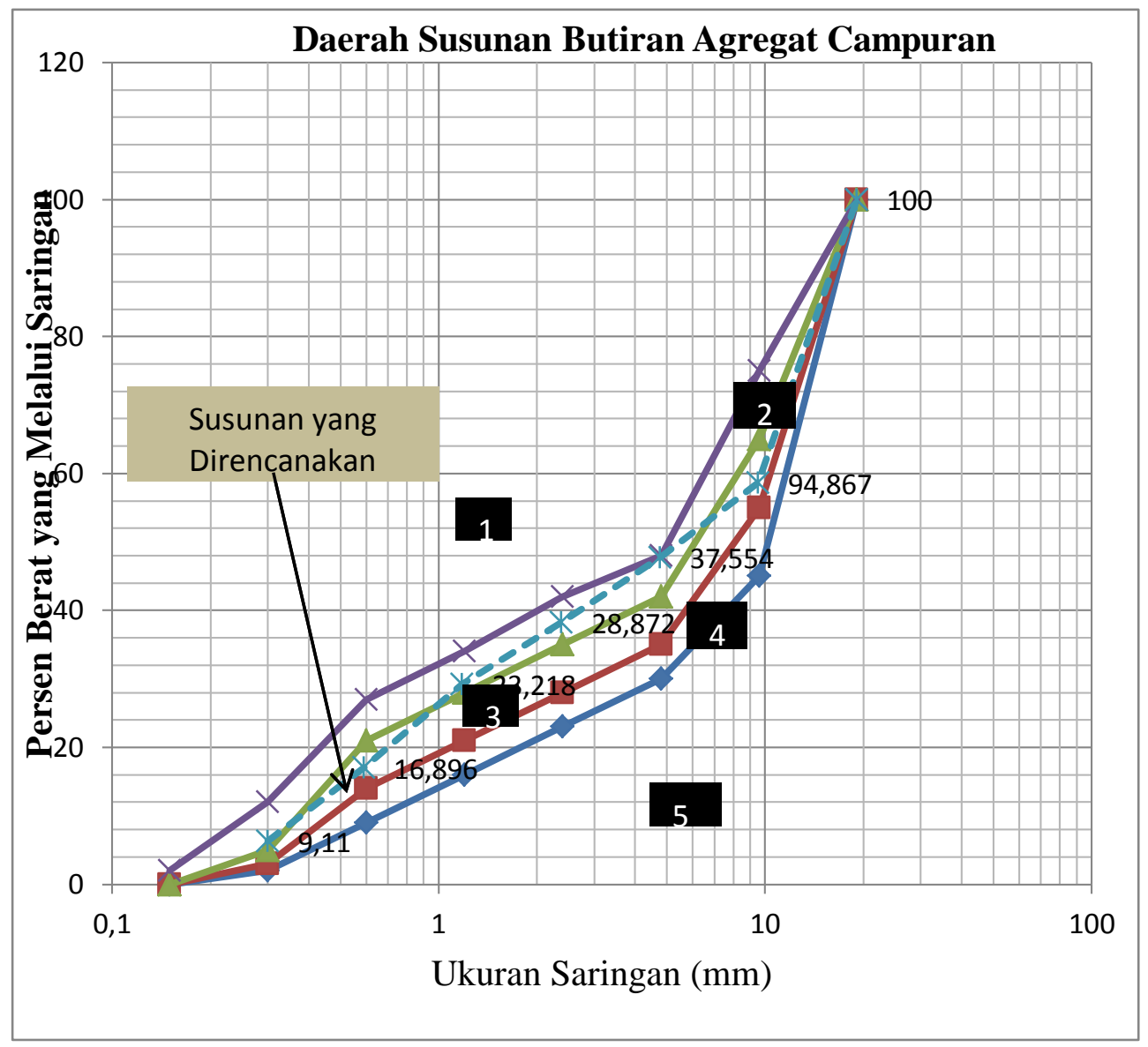

Gambar 2. Grafik Gradasi Butiran Agregat Maksimum 25,4 Mm yang Direncanakan

Tabel 4. Perbandingan Komposisi Material untuk 1 Kali Pengadukan Molen

\begin{tabular}{|c|c|c|c|c|c|c|}
\hline \multirow{2}{*}{ MATERIAL } & $\begin{array}{c}\text { CAMPURAN } \\
\mathbf{1}\end{array}$ & $\begin{array}{c}\text { CAMPURAN } \\
\mathbf{2}\end{array}$ & $\begin{array}{c}\text { CAMPURAN } \\
\mathbf{3}\end{array}$ & $\begin{array}{c}\text { CAMPURAN } \\
\mathbf{4}\end{array}$ & $\begin{array}{c}\text { CAMPURAN } \\
\mathbf{5}\end{array}$ & \multirow{2}{*}{ SATUAN } \\
\cline { 2 - 6 } & NORMAL & $\mathbf{0 , 5} \mathbf{\%} \mathbf{~ V C}$ & $\mathbf{1} \mathbf{\%} \mathbf{~ V C}$ & $\mathbf{1 , 5} \mathbf{\%} \mathbf{~ V C}$ & $\mathbf{1 , 8} \mathbf{~ V C}$ & \\
\hline AIR & 6.14 & 6.14 & 6.14 & 6.14 & 6.14 & KG \\
\hline SEMEN & 20.46 & 20.46 & 20.46 & 20.46 & 20.46 & KG \\
\hline $\begin{array}{c}\text { AGREGAT } \\
\text { KASAR }\end{array}$ & 32.5 & 32.5 & 32.5 & 32.5 & 32.5 & \multirow{2}{*}{ KG } \\
\hline PASIR HALUS & 2.63 & 2.63 & 2.63 & 2.63 & 2.63 & KG \\
\hline PASIR KASAR & 13.83 & 13.83 & 13.83 & 13.83 & 13.83 & KG \\
\hline VISCOCREATE & 0 & 0.102 & 0.205 & 0.307 & 0.368 & KG \\
\hline JUMLAH & 75.56 & 75.662 & 75.765 & 75.867 & 75.928 & KG \\
\hline
\end{tabular}

\section{Slump Test}

Pengukuran Slump Test yang dilakukan pada campuran beton segar sesuai penambahan sika viscocrete-10, disajikan dalam grafik pada Gambar 3 .
Hasil slum test agregat maksimum 25,4 mm campuran beton sebesar 7,8 $\mathrm{cm}$ kondisi normal tanpa penambahan sikaviscocrete-10, pada beton sat ditambahkan Sika Viscocrete10 terjadi penurunan nilai slump. 


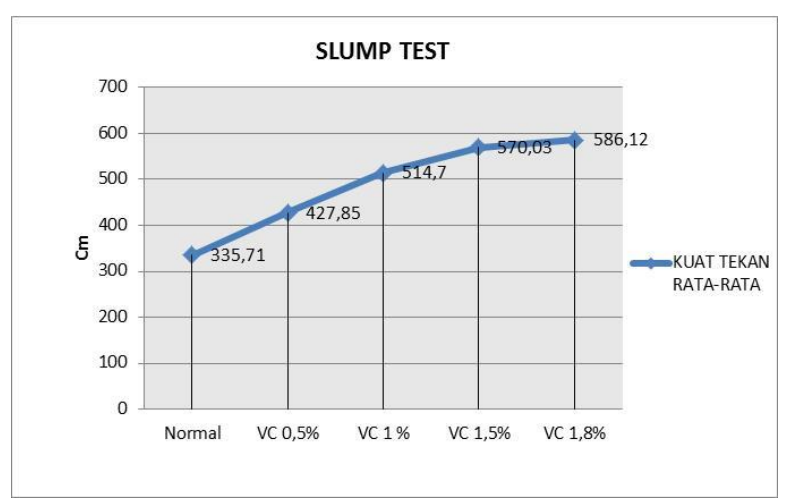

Gambar 3 : Pengaruh Penambahan Sika Viscocrete-10 dari berat semen terhadap nilai slump tes.

Adapun hasil pengukuran slump pada kondisi campuran beton segar dengan penambahan sika viscocreate-10 sebesar $0,5 \%$ dari berat semen yang dibutuhkan sesuai perhitungan mix design adalah $19,5 \mathrm{~cm}$ dan hasil pengukuran slump pada kondisi campuran beton segar dengan penambahan sika viscocreate-10 sebesar $1 \%$ dari berat semen adalah $21,9 \mathrm{~cm}$.

Untuk hasil pengukuran slump pada kondisi campuran beton penambahan sika viscocreate-10 sebesar 1,5\% sebesar $23 \mathrm{~cm}$, serta hasil pengukuran slump pada kondisi campuran

beton penambahan sika viscocreate-10 sebesar $1,8 \%$ adalah $24,7 \mathrm{~cm}$

\section{Pengujian Kuat Tekan}

Pengujian Kuat tekan dilakukan pada saat beton mencapai umur 14 hari. Sebelum dilakukan pengujian masing-masing benda uji ditimbang beratnya, dan diuji kuat tekannya. Hasil pengujian kuat tekan beton untuk benda uji silinder disajikan dalam Tabel 5.

Tabel 5. Hasil pengujian Kuat Tekan Untuk Silinder Dan Karakteristik Beton

\begin{tabular}{|c|r|r|r|c|}
\hline Benda uji & $\begin{array}{c}\text { Umur } \\
\text { Beton } \\
\text { (hari) }\end{array}$ & Faktor & $\begin{array}{c}\text { Kuat tekan } \\
\text { Beton Rata- } \\
\text { Rata } \\
\left(\mathrm{kg} / \mathrm{cm}^{2}\right)\end{array}$ & $\begin{array}{c}\text { karakteristik } \\
\text { Beton }\end{array}$ \\
\hline Normal & 14 & 0.88 & 295.43 & 277.66 \\
\hline Sika Viscrocrete10 0,5\% & 14 & 0.88 & 376.50 & 363.37 \\
\hline Sika Viscrocrete10 1\% & 14 & 0.88 & 452.94 & 427.51 \\
\hline Sika Viscrocrete10 1,5\% & 14 & 0.88 & 501.63 & 493.32 \\
\hline Sika Viscrocrete10 1,8\% & 14 & 0.88 & 515.78 & 507.48 \\
\hline
\end{tabular}

Berdasarkan Tabel 5, nilai kuat tekan beton dilakukan pada benda uji selinder dengan beton normal sebesar 295,43 kg/ $\mathrm{cm}^{2}$; beton Sika Viscocrete10 0,5\% sebesar 376,50 $\mathrm{kg} / \mathrm{cm}^{2}$; beton Sika Viscocrete10 1\% sebesar $452,94 \mathrm{~kg} / \mathrm{cm}^{2}$; Sika Viscocrete10 1,5\% sebesar $501,63 \mathrm{~kg} / \mathrm{cm}^{2}$ dan beton Sika
Viscocrete10 1,8\% sebesar $515,78 \mathrm{~kg} / \mathrm{cm}^{2}$, di atas dapat dilihat bahwa kuat tekan beton yang tertinggi terdapat pada Campuran Beton dengan menggunakan Sika Viscrocrete10 1,8\% yaitu sebesar $586,12 \mathrm{~kg} / \mathrm{cm}^{2}$ dan kuat tekan beton yang terendah terdapat pada Campuran Beton dengan menggunakan Sika 
Viscrocrete10 $0,5 \%$ yaitu sebesar 427,85 $\mathrm{kg} / \mathrm{cm}^{2}$. Pada penelitian ini karakteristik beton terbesar terdapat pada benda uji silender yang menggunakan Sika Viscocrete10 1,8\% yaitu sebesar $507,48 \mathrm{~kg} / \mathrm{cm}^{2}$.

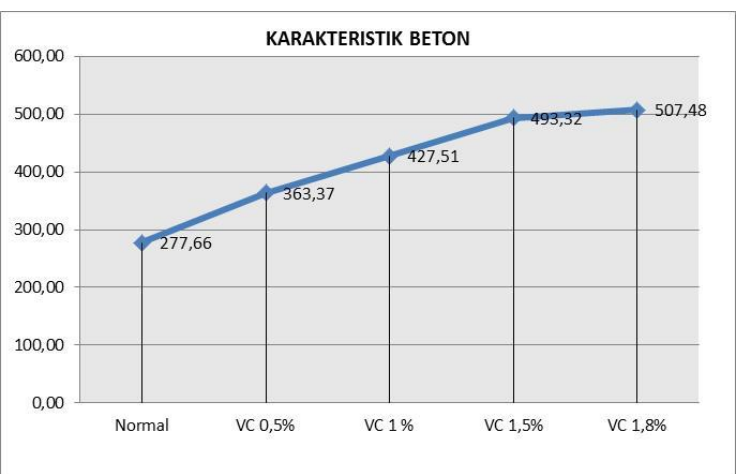

Gambar 4. Perbandingan Grafik Kuat Tekan Beton Rata-rata (menggunakan sika viscocrete-10).

Pada grafik diatas menjelaskan bahwa nilai kuat tekan beton normal untuk benda uji silinder (tanpa penambahan sika viscocrete10 ) $295,43 \mathrm{~kg} / \mathrm{cm}^{2}$, terjadi kenaikan kuat tekan rata2 dengan menggunakan sika viscocrete-10 yang nilai nya masing-masing di atas nilai beton normal. Nilai kuat tekan beton normal lebih rendah dari pada nilai kuat tekan beton menggunakan sika viscocreate10 itu disebabkan karena sika viscocreate-10 memiliki sifat daya alir yang tahan lama sehingga beton dapat memadat dengan sendiri nya, sedangkan kuat tekan beton yang paling optimal adalah dengan menggunakan sika viscocreate-10 sebanyak 1,8\% yang menghasilkan kuat tekan beton 586,12 $\mathrm{kg} / \mathrm{cm}^{2}$, pengaruh pemakaian sika viscocrete10 terbukti makin banyak menggunakan sika viscocrete-10 maka makin tinggi nilai kuat tekan beton.

\section{KESIMPULAN DAN SARAN}

\section{Kesimpulan}

Dari hasil penelitian pembuatan beton silinder dengan diameter agregat maksimum 25,4 mm, dapat diambil beberapa kesimpulan, diantaranya:

1. Hasil pemeriksaan sifat-sifat fisis agregat menunjukkan bahwa agregat yang digunakan telah memenuhi syarat berdasarkan American Concrete Institute (ACI).

2. Nilai slump yang diperoleh untuk beton normal diameter agregat maksimum $25,4 \mathrm{~mm}$ adalah $7,8 \mathrm{~cm}$. Nilai tersebut telah sesuai dengan nilai slump rencana yaitu $7,5-10$ $\mathrm{cm}$. sedangkan nilai slump untuk menggunakan sika viscocrete-10 0,5\% adalah 19,5 cm; sika viscocrete-10 $1 \%$ adalah $21,9 \mathrm{~cm}$; sika viscocrete-10 $1,5 \%$ adalah 23 $\mathrm{cm}$; sika viscocrete-10 1,8\% adalah $24,7 \mathrm{~cm}$. Berdasarkan hasil pengujian tersebut diperoleh kesimpulan bahwa penambahan sika viscocrete-10 mampu meningkatkan nilai workabilitas beton, sehingga mudah dikerjaan.

3. Kuat tekan rata - rata campuran beton normal sebesar 295,43 kg/cm²; beton Sika Viscocrete10 0,5\% sebesar $376,50 \mathrm{~kg} / \mathrm{cm}^{2}$; beton Sika Viscocrete10 $1 \%$ sebesar 452,94 $\mathrm{kg} / \mathrm{cm}^{2} ; \quad$ Sika Viscocrete10 $1,5 \%$ sebesar 501,63 kg/cm ${ }^{2}$ dan beton Sika 
Viscocrete10 $1,8 \%$ sebesar 515,78 $\mathrm{kg} / \mathrm{cm}^{2}$,

4. Pengujian kuat tekan beton menggunakan sika viscocrete10 1,8\% menghasilkan kuat tekan yang lebih besar daripada sika viscocrete10 $1,5 \% ; 1 \% ; 0,5 \%$. Perlakuan tersebut merupakan kondisi ideal yang maksimum untuk diaplikasikan.

\section{Saran}

Ada beberapa saran yang diperlukan agar mendapatkan mutu beton seperti yang diharapkan, diantaranya:

1. Berdasarkan hasil penelitian ini, nilai maksimum diperoleh pada nilai mengunakan sika viscocrete10 1,8\%, maka disarankan juga untuk diteliti dengan mengunakan zat aditif yang lain seperti Sikament-NN, Sika Fume dan lain-lain.

2. Penelitian lebih lanjut juga bisa memvariasikan persen kadar viscocrete-10 terhadap persentase berat semen (dosis menggunakan sika viscocrete10 0,5\% - 1,8\%).

\section{DAFTAR PUSTAKA}

Anonim, 1990, SNI 03-1972-1990:

“Metode Pengujian slump Beton". Pusat Penelitian dan pengembangan Jalan, Badan Penelitian dan Pengembangan PU.

Anonim, 1990, SNI 03-1974-1990: "Metode Pengujian Kuat Tekan Beton”. Bagian 3, Departemen Pekerjaan Umum dan Bahan Penelitian dan Penggembangan Pemukiman.

Anonim, 1995, Annual Book of ASTM Standard 1995, Section 4, Volume 04.02, Concrete and Aggregates, International Standard-Worldwide.

Anonim, 2002, SNI 03-2847-2002 ; “Tata Cara Perhitungan Struktur Beton Untuk Bangunan Gedung”, Departemen Pekerjaan Umum dan Bahan Penelitian dan Penggembangan Pemukiman.

Anonim, 2004, Annual Book of American Society for Testing and Materials Standard (ASTM Standard), New York, USA.

Deny Kurniawan, 2008, Regresi Linier, https://ineddeni.files.wordpress.co m/2008/07/regresi_linier.pdf

Dipuhosodo, Istimawan, 1994, Struktur Beton Bertulang, PT. Gramedia Pustaka Utama, Jakarta.

Hernando, Fandhi, 2009, Perencanaan beton mutu tinggi dengan penambahan superplasticizer dan pengaruh pengantian semen 
dengan fly ash, tugas akhir, Yogyakarta

Mulyono, Tri, 2004, Teknologi Beton, Penerbit Andi Yogyakarta.

Murdock, L.J., dan K.M., Brook, 1999, Bahan dan Praktek Beton, terjemahan Stephanus Hendarko, Erlangga, Jakarta.

Sagel, R. et al, 1993, Pedoman Pengerjaan Beton, Seri Beton 2, Erlangga.

Sjafei Amri, 2005, Teknologi Beton, Universitas Indonesia, Jakarta 